\title{
June 4th: Memory and Ethics
}

\section{Perry Link}

\section{(2) OpenEdition}

\section{Journals}

\section{Electronic version}

URL: http://journals.openedition.org/chinaperspectives/4797

DOI: 10.4000/chinaperspectives.4797

ISSN: 1996-4617

\section{Publisher}

Centre d'étude français sur la Chine contemporaine

\section{Printed version}

Date of publication: 1 June 2009

Number of pages: 4-16

ISSN: 2070-3449

\section{Electronic reference}

Perry Link, « June 4th: Memory and Ethics », China Perspectives [Online], 2009/2 | 2009, Online since 01 June 2011, connection on 28 October 2019. URL : http://journals.openedition.org/chinaperspectives/ 4797 ; DOI : 10.4000/chinaperspectives.4797

This text was automatically generated on 28 October 2019

(C) All rights reserved 


\section{June 4th: Memory and Ethics}

\section{Perry Link}

\section{ABSTRACTS}

In this essay I look first at some general problems of memory and of how events are retold from memory. Then I focus on memory of June Fourth and divide the question by asking how three categories of people-perpetrators, victims, and bystanders-have remembered, failed to remember, or tried to alter memory. The tripartite division of "perpetrators, victims, and bystanders" is not perfect but I find it illuminating. Nearly all the questions that come up have moral implications, so I call the essay "memory and ethics". I draw upon examples from literature, memoir, journalism, film, and personal acquaintance.

\section{AUTHOR}

\section{PERRY LINK}

Emeritus Professor of east Asian Studies at Princeton University. 